\title{
Insulin-Like Growth Factor Binding Protein-3 Concentrations and Insulin-Like Growth Factor Binding Protein-3 Protease Activity in Sera of Patients with Malignant Solid Tumors or Leukemia
}

\author{
HERMANN L. MÜLLER, YOUNGMAN OH, SHARRON E. GARGOSKY, KRISTIN F. WILSON, \\ THOMAS LEHRNBECHER, AND RON G. ROSENFELD
}

Department of Pediatrics, Division of Pediatric Endocrinology, Stanford University School of Medicine, SUMC, Stanford, California 94305 [H.L.M., Y.O., S.E.G., K.F.W., R.G.R.]; and Kinderklinik der Julius Maximilians Universität, D-97080 Würzburg, Germany [T.L.]

\begin{abstract}
IGF binding proteins (IGFBP) regulate the bioavailability and bioactivity of IGF. The major IGFBP in serum is IGFBP-3. We investigated whether sera from children with malignancies show alterations in levels of IGFBP-3 as measured by Western ligand blot analysis (WLB) and RIA with $\alpha$ IGFBP-3gl, a specific rabbit polyclonal antibody. Furthermore, IGFBP-3 proteolysis was quantified by densitometric analysis of [125 I]IGFBP-3 protease assays, and IGFBP-3 fragments were visualized by Western immunoblot with $\alpha$ IGFBP-3gl. We examined sera from 21 children with solid tumors, five patients with sarcoma who had reached complete remission, and 13 children with acute leukemia. Serum samples were collected at diagnosis, before initiation of therapy. Sera of 10 healthy children served as normal controls. Children with solid tumor or leukemia had significantly higher $(p<$ 0.001 ) IGFBP-3 protease activity in serum than did normal controls or patients with sarcoma in complete remission. Corresponding to this finding, densitometry of WLB showed lower IGFBP-3 levels in sera of children with malignancies in comparison with normal controls. The negative correlation $(p<0.001, r=-0.80)$ between IGFBP-3 proteolysis, as measured by [ ${ }^{125}$ I]IGFBP-3 protease assay, and IGFBP-3 band density on WLB indicates that proteolysis is the probable reason for reduction of IGFBP-3 on WLB. IGFBP-3 concentrations measured by RIA were in the normal range for most patients, further indicating that differences in serum IGFBP-3 levels measured by WLB reflect protease activity. We conclude that sera from children with malignancies frequently contain protease activity that causes IGFBP-3 cleavage in a way that might affect the tissue availability of IGF. Because many tumor cells are responsive to the mitogenic actions of IGF in vitro, IGFBP-3 proteases in serum could also play a role in tumor progression and metastasis in vivo. (Pediatr Res 35: 720-724, 1994)
\end{abstract}

\section{Abbreviations}

\section{IGFBP, IGF binding protein}

Received November 3, 1993; accepted January 25, 1994.

Correspondence and reprint requests: Hermann L. Müller, M.D., Department of Pediatrics, Division of Endocrinology, Stanford University School of Medicine, SUMC, Stanford, CA 94305-5119.

Supported in part by Grant CA58110 from the National Institutes of Health (R.G.R.), a C. J. Martin Fellowship (S.E.G.), and a Dr Mildred Scheel Stipendium, Deutsche Krebshilfe e.V. (H.I.M.).
WLB, Western ligand blot

CR, complete remission

IGF-I and IGF-II are peptide mitogens that share structural homology with proinsulin, stimulate cellular proliferation in many tissues, and may contribute to the autocrine stimulation of cell growth in a variety of tumors (1-4). Unlike most polypeptide hormones and growth factors, IGF circulate bound to specific binding proteins, which may modulate the effects of these growth factors on target tissues (5-7). To date, six distinct human IGFBP have been classified on the basis of protein and DNA sequence analysis; these have been named IGFBP-1 through IGFBP-6 $(8,9)$. The major circulating IGFBP in serum is IGFBP$3(10-12)$. An additional complexity in the regulation of IGF by IGFBP-3 has been the recently documented IGFBP proteases $(13,14)$. The IGFBP proteases degrade IGFBP-3 into smaller fragments that often display reduced affinity for IGF (14). In human beings, this IGFBP protease has been found in serum during pregnancy (13), in severely ill patients (15), and after surgery (16). Recent reports show that degradation of IGFBP-3 also may occur in sera of patients with malignant tumors because of IGFBP-3 protease (17-19).

In our study, we analyzed sera from children with malignant solid tumors or acute leukemia to address the question of whether significant IGFBP-3 proteolysis exists in sera of children with malignant solid tumors, children with acute leukemia, and children with solid tumors after reaching $C R$. We have also examined whether IGFBP-3 proteolysis in serum is a specific marker for certain tumor types.

\section{MATERIALS AND METHODS}

Patients. Twenty-six children with solid tumors [four rhabdomyosarcoma, five neuroblastoma, 12 malignant CNS tumors (four medulloblastoma, three ependymoma, five primitive neuroectodermal tumors), and five soft-tissue sarcoma in CR] and 13 children with acute leukemia (nine common-type acute lymphoblastic leukemia, two T-cell acute lymphoblastic leukemia, two acute myeloid leukemia) were included in the study. On the basis of evaluation of historical data and physical examination, patients who were severely catabolic at the time of diagnosis were excluded from the study. Criteria for exclusion were historical evidence of weight loss exceeding $10 \%$ of actual body weight, 
recent history of poor nutrition based on anamnestic data, and anorexia or physical evidence of cachexia as evaluated by physical examination. Sera from 10 healthy children who were examined for exclusion of an infection served as normal controls. IGFBP-3 levels in sera of children with malignancies were compared with an age-related SD score of normal serum IGFBP-3 levels based on serum analysis of 360 normal healthy children.

Serum samples. Blood was collected by venous puncture at the time of diagnosis, before initiation of therapy, or, in the case of the five patients with sarcoma in CR, during regular followup examination that reconfirmed the status of CR. After centrifugation, sera were stored at $-70^{\circ} \mathrm{C}$ until analysis. Informed consent was not necessary for this study because no extra blood was drawn and because only existing serum samples were used.

$W L B$ analysis. Proteins from serum samples were size fractionated by SDS-PAGE under nonreduced conditions according to the method of Laemmli (20) and then electroblotted onto nitrocellulose filters $(0.45-\mu \mathrm{m}$ pore size) with a BioTrans unit (Gelman Sciences, Ann Arbor, MI) (21). Filters were incubated overnight with $1.5 \times 10^{6} \mathrm{cpm}$ of $\left[{ }^{125} \mathrm{I}\right] \mathrm{IGF}-\mathrm{I}$ or $\left[{ }^{125} \mathrm{I}\right] \mathrm{IGF}-\mathrm{II}$, washed, dried, and exposed to X-ray film (Kodak X-Omat AR, Rochester, NY) for a period of $4 \mathrm{~d}(22)$. Band densities were analyzed with the area under the curve as calculated by densitometry (Pharmacia LKB, Columbia, MA). The relative density of the bands corresponding to IGFBP-3 on autoradiography were expressed as absorption units per millimeter.

${ }^{125}$ IJIGFBP-3 protease assay. Serum samples were assessed for IGFBP-3 protease activity as described previously (23). In brief, $2-\mu \mathrm{L}$ of serum were incubated with iodinated recombinant DNAderived IGFBP-3 produced in Escherichia coli $(30000 \mathrm{cpm})$ (Celtrix, Santa Clara, CA) in $N$-2-hydroxyethylpiperazine- $(0.1$ $\mathrm{M})$ for $5 \mathrm{~h}$ at $37^{\circ} \mathrm{C}$. Subsequently, samples were diluted with SDS-dissociation buffer and subjected to SDS-PAGE through a $4 \%$ stacking gel and a $10 \%$ separating gel under nonreducing conditions. After electrophoresis, gels were dried under vacuum and exposed to $\mathrm{x}$-ray film for a period of $18 \mathrm{~h}$ as described above. The autoradiographic intensities of the bands were determined by scanning with a densitometer. The amount of proteolysis was calculated as the percentage of the optical density of fragmented IGFBP-3 over the sum of all IGFBP-3-related optical densities.

$I G F B P-3$ RIA. The RIA for IGFBP-3 in serum was performed with a specific rabbit polyclonal antibody, $\alpha$ IGFBP-3gl by a method previously described (24). The RIA used a 1:10000 dilution of primary antiserum and a 1:20 dilution of goat antirabbit serum. Specific binding of radiolabeled IGFBP-3 produced in Chinese hamster ovary cells was $40 \%$, with $50 \%$ displacement at $1 \mathrm{ng} / \mathrm{mL}$ of unlabeled IGFBP-3 produced in Chinese hamster ovary cells. The interassay and intraassay coefficients of variation were $12 \%$ and $4 \%$, respectively. The interassay and intraassay coefficients of variation are based on a human reference serum diluted 1:100 and measured in triplicate at two points in the assay. This human reference serum was used as an internal control in every assay.

Western immunoblot analysis. Samples were subjected to nonreducing gel electrophoresis and electrotransferred to nitrocellulose as described above. The nitrocellulose was prepared as defined by the manufacturer, with the following modifications. The nitrocellulose was blocked with BSA (1\%, wt/vol) for $24 \mathrm{~h}$ and washed three times in Tween $20(0.1 \% \mathrm{vol} / \mathrm{vol})$ in a buffer containing $0.15 \mathrm{M} \mathrm{NaCl}$ and $0.1 \mathrm{M}$ Tris at $\mathrm{pH} 7.4$. The nitrocellulose was then incubated for $24 \mathrm{~h}$ with IGFBP-3 antiserum $(\alpha$ IGFBP-3gl) (24) in 1:1000 final dilution in saline buffer containing Tween $20(0.1 \%, \mathrm{vol} / \mathrm{vol})$ and washed three times for 15 $\mathrm{min}$ in Tween $20(0.1 \%, \mathrm{vol} / \mathrm{vol})$. After a 1-h incubation with goat antirabbit IgG conjugated to horseradish peroxidase in $1: 300$ final dilution, the nitrocellulose was washed in Tween 20 buffer $(3 \times 15 \mathrm{~min})$. The treated nitrocellulose was then exposed to the enhanced chemiluminescence reagents (Amersham, Arlington Heights, IL) for $1 \mathrm{~min}$, placed on plastic, and exposed to x-ray film for 4 to $60 \mathrm{~min}$.
Statistics. Values are expressed as median and range unless otherwise mentioned. Statistical comparison was performed on a Macintosh SE/30 with the statistical software package "StatWorks" (Cricket, Philadelphia, PA). The SD score of IGFBP-3 concentrations in normal serum was calculated and plotted using a three-degree polynomial equation with the software program DeltaGraph Professional (DeltaPoint, Monterey, CA). The significance of differences was estimated by $t$ test. Correlations were determined by linear regression analysis.

\section{RESULTS}

Sera from 21 children with solid tumor and 13 children with acute leukemia were analyzed before initiation of therapy and compared with sera from 10 normal controls and five patients with solid tumor (sarcoma) who had reached CR. Children with malignancies were only included in the study when they were clinically stable and not catabolic. Accordingly, the main symptom of our patients with solid tumor (rhabdomyosarcoma or neuroblastoma) was the tumor itself that had grown to a size that led to palpability or visibility. Patients with CNS tumors were diagnosed with neurologic symptoms, such as seizures or headache. No significant differences in age distribution were observed between the groups of patients with newly diagnosed malignancy and normal controls. However, the patients in complete remission were older than the other patient groups and the normal controls (Table 1).

IGFBP-3 was detectable in sera from children with malignancies and healthy controls as a 42- to 44-kD doublet by WLB (Fig. $1 A$ ). Densitometric analysis of WLB of children with malignancies showed that IGFBP-3 was reduced in sera from children with solid tumor $(p<0.001)$ or leukemia $(p<0.001)$ (Table 1 ; Fig. $2 A$ ). Children with solid tumor who had reached $C R$ showed only modestly lower IGFBP-3 on WLB $(p<0.05)$ in comparison with healthy control children.

On the other hand, IGFBP-3 serum levels measured by RIA were within the normal range (mean $\pm 2 \mathrm{SD}$ ), although they were toward the lower portion of the normal range for virtually all the children with solid tumor, acute leukemia, or solid tumor in CR (Fig. 3). Only one patient with rhabdomyosarcoma and one patient with acute leukemia had IGFBP-3 levels in serum that were slightly lower than the normal range. Such discrepancies between IGFBP-3 determinations by RIA and WLB often indicate the presence of IGFBP-3 proteolysis (24).

Proteolytic IGFBP-3 degradation was detected by [ ${ }^{125}$ I]IGFBP3 protease assay for children with malignancies (Fig. $1 B$ ). This proteolytic activity correlated negatively $(p<0.001 ; r=0.80)$ with the IGFBP-3 band density on WLB (Fig. 4), indicating that IGFBP-3 proteolysis is the probable reason for the reduction of IGFBP-3 on WLB. Furthermore, after analyzing [ ${ }^{125}$ I] IGFBP-3 protease assays, we found an identical fragment size and cleavage pattern for IGFBP-3 in sera from pregnant women and children with malignancies (Fig. $1 B$ ). This finding was confirmed on Western immunoblots, where children with malignancies showed a single immunoreactive IGFBP-3 fragment of $30 \mathrm{kD}$ (Fig. 1C). Differences in this fragment size could not be demonstrated by Western immunoblot for different tumor or leukemia types. Densitometric analysis of $\left[{ }^{125}\right.$ I] IGFBP-3 protease assays showed that children with solid tumor $(p<0.001)$ or leukemia $(p<$ 0.001 ) had significantly higher protease activity in serum than did sera from healthy control children, whereas children with solid tumors in CR had normal IGFBP-3 protease activity (Table 1; Fig. 2B).

Comparing the different types of solid tumors (four rhabdomyosarcoma, five neuroblastoma, 12 CNS tumors, five sarcoma in CR) with normal controls, we found that children with neuroblastoma had the highest protease activity in serum (61\%; range, $50-81 \%$ ) and the lowest IGFBP-3 levels on WLB (Table 1). Differences in IGFBP-3 cleavage pattern and IGFBP-3 protease 
Table 1. IGFBP-3 band density on WLB and IGFBP-3 protease activity (median) in sera from children with malignancies, normal control children, and patients with sarcomas who had reached $C R^{*}$

\begin{tabular}{|c|c|c|c|c|c|}
\hline Diagnosis & $n$ & Age $(y)$ & $\begin{array}{c}\text { Sex } \\
(\mathrm{M} / \mathrm{F})\end{array}$ & $\begin{array}{c}\text { IGFBP-3 } \\
\text { protease activity } \\
(\%)\end{array}$ & $\begin{array}{c}\text { IGFBP-3 on } \\
\text { WLB } \\
(\mathrm{AU} / \mathrm{mm})\end{array}$ \\
\hline Rhabdomyosarcoma & 4 & $6(1-13)$ & $2 / 2$ & $46(13-75) \dagger$ & $4.0(0.3-9.4)$ \\
\hline Neuroblastoma & 5 & $3(1-5)$ & $3 / 2$ & $61(50-81) \ddagger$ & $1.1(0.4-4.1) \ddagger$ \\
\hline CNS tumor & 12 & $5(2-16)$ & $7 / 5$ & $50(15-68) \ddagger$ & $2.6(0.2-6.4) \S$ \\
\hline Acute leukemia & 13 & $6(3-16)$ & $6 / 7$ & $50(31-80) \ddagger$ & $2.0(0.3-5.0) \ddagger$ \\
\hline Solid tumors in CR & 5 & $18(13-20) \ddagger$ & $2 / 3$ & $21(10-32)$ & $3.8(2.4-7.1) \dagger$ \\
\hline Normal control children & 10 & $5(2-15)$ & $5 / 5$ & $17(11-25)$ & $6.8(5.2-7.7)$ \\
\hline
\end{tabular}

* Numbers in parentheses represent ranges.

$+p<0.05$ vs normal control children.

$\ddagger p<0.001$ vs normal control children.

$\S p<0.01 v s$ normal control children.

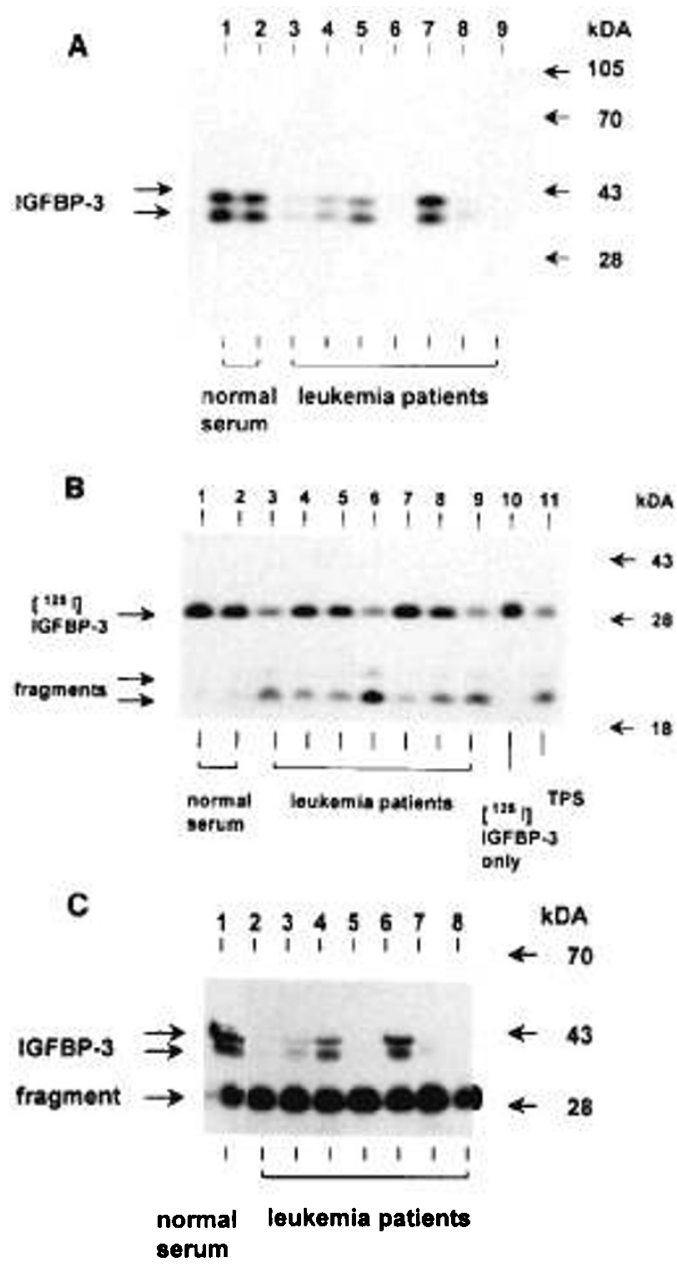

Fig. 1. $A$, WLB of sera from children with acute leukemia (common type acute lymphoblastic leukemia, lanes 3, 5, 6, 8, 9; T-cell acute lymphoblastic leukemia, lane 7; acute myeloid leukemia, lane 4; and normal control children, lanes $l$ and 2 ). $B,\left[{ }^{125}\right.$ I]IGFBP-3 protease assay of sera from the same patients as in $A$. Term pregnant serum (TPS) was run as a positive control, and [ ${ }^{125}$ I]IGFBP-3 without any serum sample added is shown as a negative control. $C$, Western immunoblot with $\alpha$ IGFBP-3gl of sera from the same patients as in $A$.

activity were not demonstrable for different types of acute leukemia (Fig. $1 B$ and $C$ ).

\section{DISCUSSION}

In our analysis of sera from children with malignancies, we have observed an impressive decrease in IGFBP-3 measured by WLB for children with either solid tumors or acute leukemia.
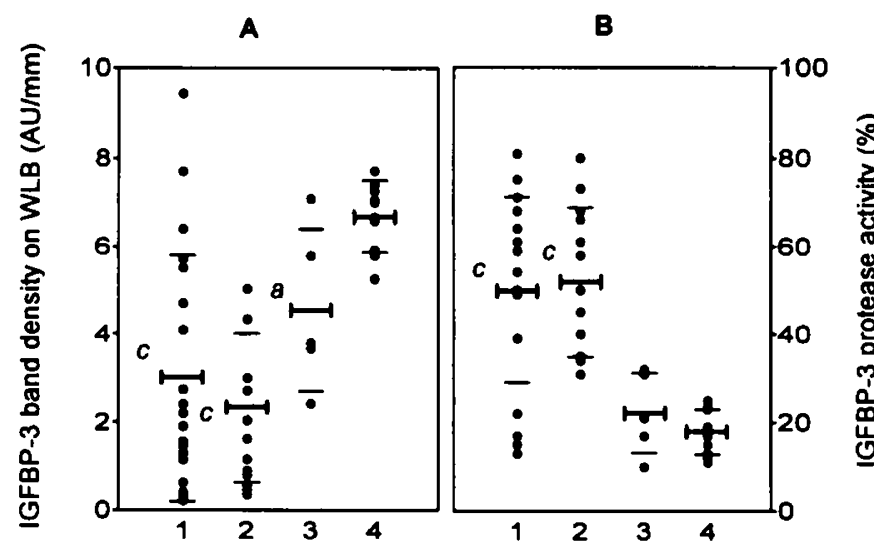

Fig. 2. $A$, Densitometric analysis of serum WLB of children with solid tumors (lane l), acute leukemia (lane 2), sarcoma in CR (lane 3), and normal control children (lane 4). The band density [absorption units per millimeter $(A U / \mathrm{mm})$ ] for IGFBP-3 on serum WLB is shown for each patient. $B$, Densitometric analysis of serum $\left[{ }^{125}\right.$ I]IGFBP-3 protease assays of the same patients as in $A$. Horizontal bars denote mean values \pm SD. The patient groups are compared with the normal controls, and statistical significant differences are expressed as $p<0.05(a), p<0.01(b)$, and $p$ $<0.001(c)$ vs normal controls.

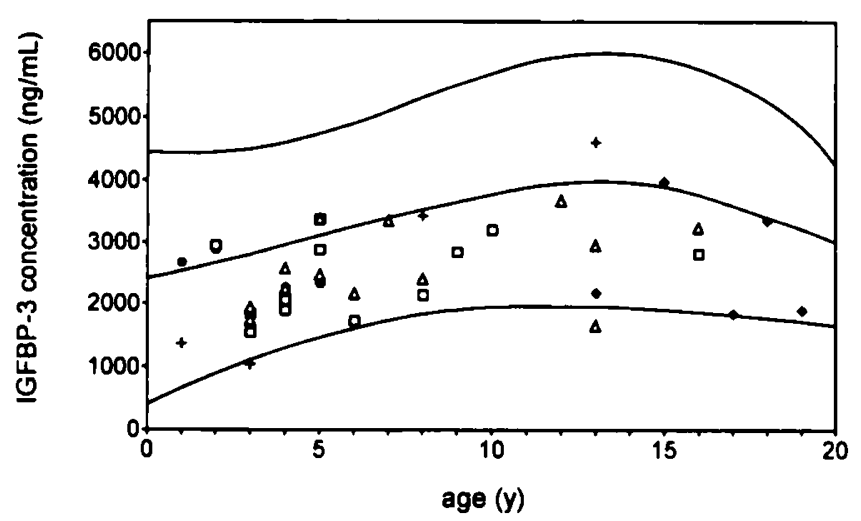

Fig. 3. IGFBP-3 concentrations $(\mathrm{ng} / \mathrm{mL})$, measured by $\mathrm{RIA}$, in serum samples of patients with malignancies $(+$, rhabdomyosarcoma;, , neuroblastoma; $\square$, CNS tumor; $\triangle$, acute leukemia; $\diamond$, sarcoma in CR). The IGFBP-3 serum level of each patient is plotted on an age-related SD score (mean $\pm 2 \mathrm{SD}$ ) for IGFBP-3 concentration in normal serum that was calculated on the basis of analysis of 360 normal healthy children.

Davies et al. (25) reported that serum IGFBP-3 decreases postoperatively in severely ill patients who have undergone abdominal surgery. Furthermore, Davenport et al. (16) characterized a serine protease in sera of adult patients after elective surgery and proposed that it is responsible for the decrease in serum IGFBP. 


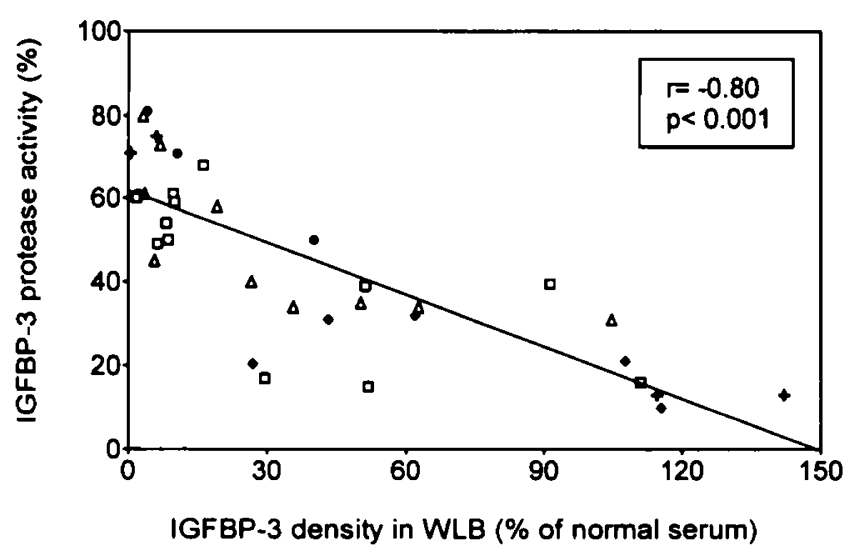

Fig. 4. IGFBP-3 protease activity (\%) as measured by [ ${ }^{125}$ I]IGFBP-3 protease assay in relationship to IGFBP-3 band density on serum WLB of patients with malignancies $(+$, rhabdomyosarcoma; $\bullet$, neuroblastoma; $\square$, CNS tumor; $\Delta$, acute leukemia; $\$$, sarcoma in CR). The IGFBP-3 band density on WLB was quantified by densitometry and is shown as percentage of the mean IGFBP-3 band density of 10 normal controls. The $R$ value and statistical significance were determined by linear regression analysis.

3 levels observed on WLB. Serum samples from most of our patients were collected before surgery and at a time when the patients were clinically stable. The only patients in this study who had undergone surgery were the five children with sarcomas who had reached CR for a period of at least 2 y after surgery. These patients showed a far less impressive reduction of IGFBP3 on WLB in comparison with children with newly diagnosed and untreated malignancies (Fig. 2A). However, the difference in comparison with normal controls still reached statistical significance $(p<0.05)$.

In accordance with the observations of Gargosky et al. (24), the reductions in IGFBP-3 on WLB were not accompanied by any alterations in IGFBP-3 serum levels as measured by RIA with a specific antibody ( $\alpha$ IGFBP-3gl). Except for one child with rhabdomyosarcoma and one child with acute leukemia, IGFBP3 values of all patients with malignancies were within the lower normal range (Fig. 3). This finding can be explained by the ability of $\alpha$ IGFBP-3gl to recognize IGFBP-3 fragments that are nondetectable by WLB technique. These IGFBP-3 fragments of 30-kD size were readily detectable by Western immunoblotting technique with $\alpha$ IGFBP-3gl, indicating that the differences in IGFBP-3 levels by WLB and RIA probably reflect protease activity. This finding is further supported by the observation that IGFBP-3 band density on WLB was negatively correlated with IGFBP-3 protease activity measured by [ ${ }^{125}$ I]IGFBP-3 protease assay (Fig. 4).

In regard to IGFBP-3 protease activity as measured by the [ ${ }^{125}$ I]IGFBP-3 protease assay, no difference was observed between normal controls and patients with sarcoma in CR, whereas children with solid tumor or leukemia at the time of diagnosis had highly elevated IGFBP-3 protease activity in sera (Fig. $2 B$ ). These results are supported by studies on adult tumor patients (17-19), which demonstrated an IGFBP-3-specific protease in sera of patients with cancer of the lung, the breast, or the head and neck area (18) and patients with prostate cancer $(17,19)$. Furthermore, we could demonstrate that IGFBP-3 proteolysis is elevated in the cerebrospinal fluid of patients with highly malignant CNS tumors (26). Interestingly, our observation that patients in CR had normal IGFBP-3 protease activity in sera may support the hypothesis that IGFBP-3 proteolysis is correlated with the existence of detectable tumor tissue. This finding is supported by other studies (17) showing that prostate specific antigen levels correlate with the stage of tumor disease and IGFBP-3 proteolysis in sera of patients with prostate cancer. Prostate specific antigen, a serine protease that cleaves IGFBP-3 in seminal plasma, serves as a serum tumor marker in prostate cancer (27). Furthermore, as observed in reports of IGFBP-3 protease activity in conditioned medium of Hs578T, a human breast cancer cell line (28), and other cancer cell lines (18), the malignant cell itself seems to be a potential source for the IGFBP3 protease. However, prospective longitudinal studies are necessary to address the question of whether IGFBP-3 proteolysis in serum correlates with detectable tumor tissue.

In conclusion, IGFBP-3 proteolysis was increased in serum samples of children with solid tumor or acute leukemia at the time of diagnosis without specificity for any tumor or leukemia type. This proteolytic activity was normalized in serum samples from patients who had reached CR. IGFBP-3 fragments resulting from high protease activity in sera show reduced affinity for IGF (14), which may affect the tissue availability of IGF. Because many tumor cells are responsive to the mitogenic actions of IGF, such an effect could play a role in cancer progression. Measures of IGFBP and IGFBP proteolytic activity warrant further investigation as potential diagnostic parameters in the evaluation of cancer.

\section{REFERENCES}

1. Daughaday WH, Deuel TF 1991 Tumor secretion of growth factors. Endocrinol Metab Clin North Am 20:539-563

2. Froesch ER, Schmid C. Schwander J, Zapf J 1985 The biological actions of the insulin-like growth factors. Annu Rev Physiol 47:443-467

3. El-Badry OM, Romanus JA, Helman LJ, Cooper MJ, Rechler MM, Israel MA 1989 Autonomous growth of a human neuroblastoma cell line is mediated by insulin-like growth factor II. J Clin Invest 84:829-839

4. Minniti CP, Kohn EC, Grubb JH, Sly WS, Oh Y, Müller HL, Rosenfeld RG, Helman LJ 1992 The insulin-like growth factor II (IGF-II)/mannose 6phosphate receptor mediates IGF-II-induced motility in human rhabdomyosarcoma cells. J Biol Chem 267:9000-9004

5. Rosenfeld RG, Pham H. Conover CA, Hintz RL, Baxter RC 1989 Structural and immunological comparison of insulin-like growth factor (IGF) binding proteins of cerebrospinal and amniotic fluids. J Clin Endocrinol Metab 68:638-646

6. Baxter RC, Bayne ML. Cascieri MA 1992 Structural determinants for binary and ternary complex formation between insulin-like growth factor (IGF)-I and IGF-binding protein-3. J Biol Chem 267:60-65

7. Conover CA, Liu F, Powell D, Rosenfeld RG, Hintz RL 1989 Insulin-like growth factor binding proteins from cultured human fibroblasts. J Clin Invest 83:852-859

8. Ballard F, Baxter R, Binoux M. Clemmons D. Drop S. Hall K. Hintz R. Rechler R, Rutanen E, Schwander J 1989 On the nomenclature of IGF binding proteins. Acta Endocrinol (Copenh) 121:751-752

9. Rosenfeld RG, Lamson G, Pham H, Oh Y, Conover C, De Leon DD, Donovan SM, Ocrant I, Giudice L 1990 Insulin-like growth factor binding proteins. Recent Prog Horm Res 46:99-163

10. Blum WF, Ranke MB, Bierich JR 1986 Isolation and partial characterization of six somatomedin-like peptides from human plasma Cohn fraction IV. Acta Endocrinol (Copenh) 111:271-284

11. Moses AC, Nissley SP, Passamani J, White RM 1979 Further characterization of growth hormone-dependent somatomedin-binding proteins in rat serum and demonstration of somatomedin-binding proteins produced by rat liver cells in culture. Endocrinology 104:536-546

12. Martin JL, Baxter RC 1986 Insulin-like growth factor binding proteins from human plasma. J Biol Chem 261:8754-8760

13. Giudice LC, Farrell EM, Pham H, Lamson G, Rosenfeld RG 1991 Insulinlike growth factor binding proteins in maternal serum throughout gestation and in the puerperium: effects of a pregnancy-associated serum protease activity. J Clin Endocrinol Metab 71:806-817

14. Hossenlopp P. Seurin B, Lassarre C, Roghani M, Breddon M, Binoux M 1990 Evidence for enzymatic degradation of insulin-like growth factor binding proteins in the $150 \mathrm{kDa}$ complex. J Clin Endocrinol Metab 71:797-805

15. Holly JMP, Davies SC, Cotterill AM, Coulson VJ, Ross RJM, Miell JP, Abdulla AF, Wass AJM 1991 Severe illness induces an IGFBP-3 specific protease in the circulation, the activity of which is nutritionally dependent. Program of the Second International IGF Symposium, 1991, San Francisco, C48 (abstr)

16. Davenport ML, Isley WL, Pucilowska JB, Pemberton LB, Lyman B, Underwood LE, Clemmons DR 1992 Insulin-like growth factor-binding protein-3 proteolysis is induced after elective surgery. J Clin Endocrinol Metab 75:590595

17. Kanety H, Madjar Y, Dagan Y, Levy J, Papa MZ, Pariente C, Goldwasser B, Karasik A 1993 Serum insulin-like growth factor-binding protein-2 (IGFBP2 ) is increased and IGFBP-3 is decreased in patients with prostate cancer: correlation with serum prostate-specific antigen. J Clin Endocrinol Metab 77:229-233

18. Holly JMP, Claffey DCP. Cwyfan-Hughes SC, Frost VJ, Yateman ME 1993 Proteases acting on IGFBPs: their occurrence and physiological significance. Growth Regul 3:88-91 
19. Lamson G, Giudice LC, Cohen P, Liu F, Gargosky SE, Müller HL, Oh Y, Wilson KF, Hintz RL, Rosenfeld RG 1993 Proteolysis of IGFBP-3 may be a common regulatory mechanism of IGF action in vivo. Growth Regul 3 91-95

20. Laemmli UK 1970 Cleavage of structural proteins during the assembly of the head of bacteriophage T4. Nature 227:680-685

21. Towbin H, Staehlin T, Gordon J 1979 Electrophoretic transfer of proteins from acrylamide gels to nitrocellulose sheets: procedure and some applications. Proc Natl Acad Sci USA 76:4350-4354

22. Hossenlopp P. Seurin D, Seqouia-Quinson B, Hardouin S. Binoux M 1986 Analysis of serum insulin-like growth factor binding proteins using western blotting: use of the method for titration of binding proteins and competitive binding studies. Anal Biochem 54:138-143

23. Lamson G, Giudice LC, Rosenfeld RG 1991 A simple assay for proteolysis of IGFBP-3. J Clin Endocrinol Metab 72:1391-1393

24. Gargosky SE, Pham HM, Wilson KF, Liu F, Giudice LC, Rosenfeld RG 1992 Measurement and characterization of insulin-like growth factor binding protein-3 in human biological fluids: discrepancies between radioimmunoassay and ligand blotting. Endocrinology 131:3051-3060

25. Davies SC, Wass JAH, Ross RJM, Cotterill AM, Buchanan CR, Coulson VJ, Holly JMP 1991 The induction of a specific protease for insulin-like growth factor binding protein-3 in the circulation during severe illness. J Endocrinol 130:469-473

26. Müller HL, Oh Y, Gargosky SE, Lehrnbecher T, Hintz RL, Rosenfeld RG 1993 Concentrations of insulin-like growth factor binding protein-3 (IGFBP. 3), insulin-like growth factors (IGF) and IGFBP-3 protease activity in cerebrospinal fluid (CSF) of children with leukemia, central nervous system (CNS) tumor or meningitis. J Clin Endocrinol Metab 77:1113-1119

27. Stamey TA, Yang N, Hay AR, McNeal JE, Freiha FS, Redwine E 1987 Prostate specific antigen is a serum marker for adenocarcinoma of the prostate. N Engl J Med 317:909-918

28. Oh Y. Müller HL, Pham H, Lamson G, Rosenfeld RG 1993 Insulin-like growth factor binding protein (IGFBP)-3 levels in conditioned media of Hs578T human breast cancer cells are posttranscriptionally regulated. Growth Regul 3:84-87 